\title{
O FUNCIONAMENTO DO DISCURSO RELIGIOSO NAS POLÍTICAS DE RESSOCIALIZAÇÃO
}

\author{
JOELMA APARECIDA BRESSANIN ${ }^{1}$ \\ MARICLEI EDUARDO CINTRA BARRETO
}

Programa de Pós-Graduação em Linguística - Universidade do Estado de Mato Grosso Av. Santos Dumont, Cidade Universitária - 78200-000 - Cáceres-MT - Brasil

joelmaab@hotmail.com ; maricleicintra@yahoo.com.br

\begin{abstract}
Resumo. O presente estudo se filia à teoria da Análise de Discurso proposta por Pêcheux, na França, e desenvolvida por Orlandi, no Brasil. Pautamonos na análise de recortes discursivos de entrevistas desenvolvidas com sujeitos presos em uma unidade prisional de Cuiabá-MT, objetivando compreender o funcionamento do discurso religioso nas políticas de ressocialização.
\end{abstract}

Palavras-chave: ressocialização; sujeitos; sentidos; religião; ideologia.

\begin{abstract}
This study joins the theory of discourse analysis proposed by Pêcheux in France and developed by Orlandi in Brazil. We have carried out discursive analysis of interviews undertaken with prisoner subjects in a prison of Cuiaba-MT, aiming to understand the functioning of religious discourse function within resocialization policies.
\end{abstract}

Keywords: resocialization; subject; meanings; religion; ideology.

\section{Apresentação}

O presente trabalho resulta de uma pesquisa que desenvolvemos no Mestrado sobre os sentidos de ressocialização para os sujeitos segregados no Centro de Ressocialização de Cuiabá (CRC), pelo viés da Análise de Discurso de linha francesa. Para construir a análise, utilizamos como corpus entrevistas semiestruturadas, as quais foram gravadas e transcritas. Ao todo foram entrevistados vinte sujeitos que estão cumprindo pena de privação de liberdade por situações diversificadas. As entrevistas foram realizadas entre os meses de setembro e outubro de 2015 e a escolha dos sujeitos participantes foi feita pelos funcionários do $\mathrm{CRC}$, em atenção aos critérios que solicitamos previamente, quais sejam, que fossem chamados sujeitos de várias faixas etárias, de alas diferentes, condenados e provisórios, participantes e não participantes de igrejas, das atividades extramuros, da escola e, ainda, homossexuais que permanecem em espaços específicos no CRC.

\footnotetext{
${ }^{1}$ Doutora em Linguística (Unicamp). Professora da Graduação em Letras e no Programa de Pós-Graduação em Linguística da Universidade do Estado de Mato Grosso (UNEMAT).

${ }^{2}$ Mestre em Linguística (UNEMAT).
} 
Para esse artigo, selecionamos cinco recortes, nos quais observamos, em meio a uma rede de sentidos que circulam no referido espaço, o modo como os sujeitos entrevistados, individuados pelo Estado, pelas instituições e pelos discursos, em um processo de identificação, inscrevem seu dizer numa dada formação discursiva.

Desse modo, por meio de um percurso sócio-histórico e político de constituição das prisões, buscamos compreender o modo como o discurso religioso, atravessado pelo discurso disciplinar, significa as políticas de ressocialização e o modo como os sujeitos se significam em face dessas políticas.

\section{Das prisões aos Centros de Ressocialização}

Em relação às prisões, observamos que a própria terminologia nos remete ao funcionamento da memória no que tange à prática religiosa e aos gestos de punir, castigar, pois, a palavra penitenciária é derivada da aplicação da pena (Prisão Eclesiástica) de enclausuramento dos clérigos e monges nos mosteiros da Idade Média; monges que desobedeciam às regras e os preceitos religiosos e eram colocados em isolamento para se dedicarem à meditação e se arrependerem da falta cometida, reconciliando-se com Deus. Essa prática inspirou a construção de instituições-prisão destinadas ao recolhimento de criminosos para se arrependerem dos maus atos cometidos.

A forma de punição predominante até final do século XVII, ou meados do século XVIII, eram os castigos corporais, através de um verdadeiro espetáculo, chamado de suplício, de acordo com Foucault (2013). A partir do século XVIII, a prisão com a restrição da liberdade passa a ter papel da punição prática e é tratada com humanização das penas que deixam de ser cruéis e desumanas. Para o autor, a punição dos criminosos se transforma, em grande parte, porque o jeito de exercer o poder também modificou.

Foi a partir de alguns acontecimentos históricos, como a Revolução Francesa e a Revolução Industrial, que ocorrem reformulações importantes no sistema penal, uma vez que, com as modificações da forma de organização Estatal, o ato de punir deixa de ser prerrogativa do monarca e passa a ser um direito da sociedade de se defender contra aqueles indivíduos que oferecessem risco à propriedade e à vida, com a racionalização da pena de restrição de liberdade. Para cada crime, uma determinada porção de tempo seria retirada do sujeito que o praticasse e esse tempo seria regulado e usado para se obter um perfeito controle do corpo e da mente do indivíduo pelo uso de determinadas técnicas de poder.

Assim, a privação da liberdade do sujeito ao mesmo tempo constitui-se num dos aparelhos utilizados pelo Estado para repressão (ARE), que, de acordo Althusser (1985, p. 45), "atuam em conjunto com os Aparelhos Ideológicos do Estado (AIE), sendo exemplos desses últimos as Igrejas, as Escolas, as Famílias, os Sindicatos e outros". Observamos, em nossa pesquisa, a atuação de um AIE (igreja) em conjunto com um ARE (prisão) desde as primeiras formalizações de leis que legitimavam as punições e a existência das prisões.

Segundo Maia (2009), 
os internatos, conventos, hospitais, quartéis e fábricas - todas instituições totais, isto é, aquelas que tinham por finalidade administrar a vida de seus membros, mesmo que à revelia de sua vontade, num esforço de produzir a racionalização de comportamentos - seriam os protótipos das prisões. (MAIA, 2009, p. 13)

Para a autora, essas instituições totais eram destinadas às funções de punir, defender a sociedade do malfeitor e, ainda, de corrigir o delinquente.

Ainda, segundo Foucault (2013), na Idade Média, não existiam muitas edificações construídas especificamente para serem prisões; prevalecia a prisão provisória até o julgamento, destacando-se que as penas aplicadas correspondiam, ainda que em grau pequeno, os castigos corporais (amputação de braços, degolamento, enforcamento, a escravidão), assegurando o espetáculo e a dor dos infratores.

Os modelos de prisões modernas surgem como uma nova tecnologia do poder de punir, razão que tornara a reforma penal essencial no século XVIII, com a necessidade de colocar um princípio de moderação ao poder do castigo. Para a materialização dessa punição aos que se opunham às normas estatais, surge a primeira instituição penal, ou melhor, penitenciária, construída oficialmente no mundo, o Hospício de San Michel, em Roma, que foi nomeada como "Casa de Correção".

Em 1787, o inglês Jeremy Bentham (1748-1832) escreve "Panóptico", que seria, para a época, uma penitenciária modelo que ainda subsiste nos princípios das instituições sociais que apresentam certo controle, como escolas, quarteis, indústrias, entre outros. Segundo Foucault (2013), essa simples vigilância proporcionaria mais virtude às pessoas, que poderiam aprender a ser mais úteis à sociedade.

No início do século XIX, aparecem, na Filadélfia, presídios que apresentavam um sistema celular, ou sistema da Filadélfia, como se tornou conhecido. O que se pretendia naquele momento era a disciplinarização dos corpos em primeira instância, o que significava uma maneira de transformar corpos e mentes rebeldes em instrumentos dóceis, fáceis de serem controlados (FOUCAULT, 2013).

E nessa direção, pautados nos preceitos de disciplina, trabalho, isolamento e leitura religiosa como medidas de recuperação, no ano de 1820, surge nos Estados Unidos outro modelo de prisão, o qual foi denominado "Sistema Auburn" ou "Sistema de Nova Iorque", caracterizado por apresentar a reclusão e o isolamento absoluto no período noturno e ainda a regra de silêncio absoluto entre os presos nos momentos que saiam das celas para trabalhar e fazer refeições, marca que definiu esse sistema e lhe rendeu severas críticas.

Quarenta anos mais tarde, em Norfolk, uma colônia inglesa, os aplicadores do direito penal reúnem os dois sistemas, o da Filadélfia e o de Auburn. Posteriormente, surge também o Sistema de Borstal, que visava a conceder instrução moral e profissional, destacando-se por implantar o modelo de prisão aberta.

Em razão das condições de produção, em diversas localidades, apareciam sistemas de prisões próprios, destacando-se o que a Espanha aplicou, por oferecer remuneração aos trabalhos desenvolvidos pelos presos, e, ainda, o sistema de trabalhos na zona rural 
preconizado pela Suíça. Este, ainda hoje, vige em nosso ordenamento jurídico com a denominação de Colônias Agrícolas.

De modo geral, vemos que as diferentes formas de punição e de correção vão sendo legitimadas pelos novos sistemas de aplicação da pena de prisão que foram implementados baseados na disciplina, efetivação de trabalhos e em algumas privações aos apenados, consagrando-se enquanto justiça assimétrica das sujeições disciplinares (FOUCAULT, 2013).

Podemos, então, afirmar que é, com a Revolução Francesa (1789-1799), a Declaração de Direitos Humanos e a Revolução Industrial, que temos a materialização do discurso de humanização das penas que sustentam os discursos das políticas públicas pautadas na ressocialização do sujeito que tenha cometido delito, objetivando transformálo.

$\mathrm{Na}$ atual conjuntura, os presídios se tornam Centros de Ressocialização (CR). Primeiramente, foram instalados no Estado de São Paulo, a partir dos anos 2000, através do Decreto $\mathrm{n}^{\circ}$. 45.271. Essas instituições configuram-se em presídios de pequeno porte, destinados a presos de baixa periculosidade que se encontram em regime fechado, semiaberto e provisório.

No estado de Mato Grosso, o presídio Carumbé passa a ser chamado de Centro de Ressocialização de Cuiabá (CRC) oficialmente, no ano de $2005^{3}$. Tal mudança foi publicada no Diário Oficial do Estado, em fevereiro de 2005; e, por decreto, fora instituído o novo nome, com objetivos voltados à ressocialização do sujeito que se encontra privado de sua liberdade na instituição, em conformidade com a política de controle social desenvolvida nos demais Centros já existentes no país.

O CRC está situado no bairro Carumbé, no município de Cuiabá, Estado de Mato Grosso, região próxima a bairros residenciais e comerciais e a órgãos públicos (delegacias, Vara da Infância e Juventude, Ministério Público). Possui capacidade para abrigar 300 presos do gênero masculino, todavia, está com mais de 773 jovens e adultos em regime de privação de liberdade.

A construção arquitetônica é relativamente antiga, da década de 70, e vem sendo reformada aos poucos, de acordo com as possibilidades de verbas públicas, sempre no sentido de ampliação e adequação para a aplicação das políticas voltadas para a ressocialização, visando à construção e reforma de espaços que são destinados a áreas de atividades laborais, salas de aula, salas para atendimento de profissionais como psicólogos, defensores públicos, médicos, entre outros.

Os Centros de Ressocialização se apresentam enquanto uma nova experiência na prática de encarceramento, um "modelo" de instituição prisional, em que as diferenças estruturais e a administração compartilhada entre Estado e ONGs contribuem para essa legitimação discursiva, voltada às políticas públicas que ensejam a ressocialização do sujeito condenado por meio da educação, trabalho e religião, como acontece no CRC,

\footnotetext{
${ }^{3}$ Toda a documentação acerca da concretização desse ato perdeu-se num incêndio que aconteceu na própria instituição, o qual consistiu, segundo relatos de alguns sujeitos entrevistados e servidores antigos, na última rebelião ocorrida dentro da unidade com repercussão nacional.
} 
com a participação da Secretaria de Estado de Educação (Seduc), com o funcionamento de uma unidade escolar dentro do CRC - não por acaso denominada Escola Estadual Nova Chance -, e com a OAB, SENAI, SESI, ROTARY, entre outros, que promovem cursos, palestras e divulgam os artesanatos produzidos pelos sujeitos segregados nesse espaço.

Ainda que a Constituição da República Federativa do Brasil (1988) traga em seus artigos e incisos a previsão de uma sociedade democrática pautada no princípio humanitário da pena e o presídio Carumbé tenha se tornado um Centro de Ressocialização, não deixou de ser um espaço de controle social. A esse respeito, consideramos, conforme Orlandi (2010), que, discursivamente, "o espaço significa, tem materialidade e não é indiferente em seus distintos modos de significar, de enquadrar o acontecimento" (p. 6). Para a autora, todo discurso está sempre sendo relacionado a outros, em espaços e tempos sociais, ou seja, é a inserção do sujeito num determinado lugar e tempo que o torna essencialmente ideológico e histórico.

A mudança de nome de presídio Carumbé para Centro de Ressocialização de Cuiabá-MT nos chamou a atenção para o funcionamento simbólico dessa prática institucionalizada, pois, a nosso ver, esse processo passa a atuar no imaginário do preso, da sociedade, produzindo efeitos de garantia dos princípios da política de ressocialização dos sujeitos privados de liberdade.

Capeller (1985) afirma que o conceito "ressocialização" surgiu com o desenvolvimento das ciências sociais comportamentais, no século XIX; e é fruto da ciência positivista do direito, refletindo com clareza o binômio ideologia/repressão. Ela ainda afirma que o discurso jurídico se apropria do conceito de ressocialização com o sentido de reintegração social dos indivíduos, enquanto sujeitos de direito, procurando ocultar a ideia do castigo e a figura do Estado opressor.

O conceito de ressocialização é integrante do discurso jurídico e justifica a pena privativa da liberdade, como forma de criar nos indivíduos uma disciplina que permita a convivência com os demais integrantes da sociedade. O termo estaria ligado ao fato do indivíduo privado de liberdade, através das práticas punitivas, passar a respeitar as normas penais, tendo como principal objetivo o de que, no futuro, ele não volte a cometer delitos.

Inserido nessa nova conjuntura está o CRC, voltado para a reinserção social do sujeito, afetado pelo funcionamento do contraditório, capaz de uma posição sujeito também logicamente contraditória com a emergência de efeitos de sentidos pela ressocialização e pelo estigma de estar preso, uma vez que o CRC também não deixa de ser uma prisão. Nos entremeios da humanização nas prisões e dos princípios de ressocialização do sujeito, esse sujeito segregado sofre algumas mazelas oriundas das práticas de intimidação empreendidas por alguns grupos que assumem a organização do $\mathrm{CRC}$, impondo penalizações e castigos corporais àqueles que descumprem as normas estabelecidas internamente.

Nessa direção, concordamos com Adorno de Oliveira (2015), ao afirmar que estamos imersos num universo gerido pelo capitalismo e pelo jurídico - no formato de leis, que são promulgadas para responderem às necessidades de um determinado 
momento, produzindo sentidos que são questionados em suas textualidades, não como espaço sem falhas, mas na constituição de seu discurso.

Então, a lei interpreta e produz significados sobre os fatos apresentados socialmente e viabiliza possíveis soluções às questões impostas pelo capital, produzindo sentidos de segurança e, ao mesmo tempo, camuflando as (não) condições daqueles que se encontram à margem, sendo essa a realidade constitutiva dos discursos que significam o processo de ressocialização voltado para a recuperação dos sujeitos privados de liberdade.

\section{Uma compreensão discursiva sobre o assujeitamento}

Pensar no processo de reinserção do sujeito, que está em uma unidade prisional cumprindo pena de prisão, remete-nos aos diferentes modos de separação entre os sujeitos que se estabelecem nas relações sociais. Na concepção discursiva, as relações sociais, atualmente, não são de classes, mas de lugares, e se representam horizontalmente: ou se está dentro ou se está fora, de acordo com Orlandi (2010). Logo, as relações são de segregação e, uma vez segregado, torna-se impossível ao sujeito entrar nas relações sociais.

Para a autora, na configuração da sociedade atual, as relações sociais são marcadas por práticas de segregação, cujo par inclusão/exclusão tem em sua constituição a contradição. Segundo Orlandi (2014, p. 98), há
discursos que trabalham a ilusão da relação incluir/excluir como se a sociedade capitalista fosse a da oportunidade, como se 'bastasse' o sujeito estudar, trabalhar, ser competente, disciplinado, ter boa vontade para conquistar seu lugar (ao sol). São discursos que colocam o sujeito como 'responsável' por alcançar seu lugar.

Os discursos de inclusão corroboram para a responsabilização do próprio sujeito, como se, através da oportunidade dada pelo Estado ao sujeito, este pudesse ter "acesso" a um lugar na sociedade. Orlandi destaca que o sujeito, além de ser assujeitado pelo social, pelo histórico e pela ideologia, também se relaciona com a língua de forma material, esclarecendo que a $\mathrm{AD}$ "não trabalha com a língua enquanto um sistema abstrato, mas com a língua no mundo" (2013, p. 15-16), isto é, trabalha com a língua em sua materialidade.

Dessa forma, destacamos que o conceito de ideologia não se desvincula da noção de sujeito, uma vez que o sujeito deve ser considerado sempre como um ser socialhistórico-ideológico, apreendido em um espaço coletivo, uma vez que ele é sujeito à língua e à história e, para se constituir e (se) produzir sentidos, é afetado por elas.

Segundo Haroche (1992), a etimologia nos ensina que o sentido primeiro de "sujeito" (surgido no século XII) significa: "submetido à autoridade soberana". "Sujeição" aparece igualmente na mesma época, no século XV; e são dela derivadas as palavras "assujeitar" e "assujeitamento". 
Discursivamente, pensamos o sujeito enquanto forma-sujeito. Ou seja, o sujeito da Idade Média era submetido aos discursos religiosos - às leis da Igreja -, o que correspondia à forma-sujeito-religioso. No mundo contemporâneo, o Estado opera um poder sobre o sujeito, que se encontra submisso às leis do Estado, na forma de sujeito-dedireito (HAROCHE, 1992; ORLANDI, 2013). Por esse viés, Orlandi (2013) afirma que a forma sujeito-histórica que corresponde à da sociedade atual representa bem a contradição: é um sujeito ao mesmo tempo livre e submisso. Essa é a base do que se considera assujeitamento.

É sob essa perspectiva que propomos compreender o modo como os discursos religiosos constituem o imaginário de castigo, de prisão, sustentando os argumentos daqueles que estão privados de liberdade no CRC. Esses sujeitos se inscrevem em diferentes formações discursivas, uma vez que há o processo de interpelação dos indivíduos em sujeito pela ideologia. Daí o Estado extirpa-lhes o direito de ir e vir, previsto na $\mathrm{CF}$, através dos seus aparelhos repressores do Estado (ARE): o exército, a polícia, os tribunais e a prisão (ALTHUSSER, 1985); e implanta seus aparelhos ideológicos (AIE) de Estado: o sistema de diferentes igrejas, o sistema escolar, o sistema familiar, o sistema jurídico, o sistema político, o sistema sindical, o sistema de informação e o sistema cultural.

$\mathrm{Na}$ condição de assujeitado ao Estado, o sujeito segregado, que é também o que está do lado de fora da sociedade, ao se identificar com as formações discursivas, vai se ressignificando pelo discurso. Nesse movimento, a forma-sujeito histórica capitalista e o processo de individuação pelo Estado, que falha pela falta (ORLANDI, 2010), fazem funcionar a engrenagem para que sejam postos e mantidos na posição de sempre segregados, em consonância com Silva (2014).

Contudo, por ser assujeitado, esse sujeito não deixa de se fazer (se significar) na/pela história, uma vez que, na $\mathrm{AD}$, consideramos que a ideologia se materializa na linguagem, de acordo com Orlandi (2013). E, se a linguagem é o lugar de materialização da ideologia, então, podemos concluir que esta opera no inconsciente e que seu funcionamento é pela evidência.

Para Pêcheux (1995), uma palavra, uma expressão, uma proposição não promove existência de sentido em si mesma; esta é determinada pelas posições ideológicas que estão em jogo no processo sócio-histórico no qual as palavras, expressões ou proposições são produzidas. Elas mudam de sentido segundo "as posições sustentadas por aqueles que as empregam, em referência às posições ideológicas nas quais essas posições se inscrevem", conforme nos esclarece Pêcheux (1995, p. 160).

O conjunto de formações discursivas, por conseguinte, forma o interdiscurso, que também está afetado pelas formações ideológicas. Isso nos permite compreender que é no lugar discursivo que o sujeito se inscreve em uma determinada formação discursiva, Nessa direção, observamos que os sujeitos segregados que estão no CRC, por meio da antecipação, fazem uma projeção imaginária do seu receptor, e, a partir daí, estabelecem suas estratégias discursivas; assim, quando estão conversando, pessoas da administração da unidade, representantes do Poder Judiciário, e até seus familiares, são afetados pelas perspectivas de reinserção social. Entram em jogo as imagens que resultam dessas projeções. 
Diante do exposto, parafraseando o fundador da $\mathrm{AD}$, é a formação ideológica que regula o que o sujeito pode ou não dizer, mas com a ilusão de ser fonte do discurso. Assim, o sujeito segregado que está no CRC produz discursos sobre recuperação, reintegração social, necessidade de ter uma profissão e ainda se inserir em práticas religiosas, mas todos esses dizeres já estão ideologicamente marcados pela atuação do Estado.

Entendemos que o cárcere é imposto à sociedade sob o argumento de "transformar pessoas". Mas este discurso oficial necessita ser analisado a partir dos efeitos que o encarceramento promove no indivíduo quando ele é interpelado pelas ideologias ali vigentes, uma vez que a história não é transparente, nem os sentidos são evidentes. Para a $\mathrm{AD}$, portanto, os sentidos não estão na língua, mas nas relações que ela estabelece com a exterioridade, com os processos discursivos, conforme as palavras de Pêcheux (1995).

O sujeito segregado pensa ser o sujeito responsável e organizador de seu discurso, justamente por ocupar o lugar social, lugar de segregado numa prisão. Então, quando deixa o espaço empírico e passa para o espaço discursivo, o sujeito segregado inscrevese num determinado lugar discursivo, o qual está determinado pelas relações da instituição que ele representa socialmente, no nosso caso, do CRC. Assim, podemos acrescentar que a posição de um sujeito não é igual em todos os lugares, considerando que ele é um sujeito histórico, assujeitado ideologicamente, ocupando um lugar na formação social que o constitui. Dessa forma, o sujeito sempre enuncia de um determinado lugar social, o qual é afetado por diferentes relações de força e de poder, e isso é constitutivo do seu discurso.

No caso dos sujeitos segregados, inseridos no atual sistema capitalista e assujeitados às políticas de ressocialização do Estado, na forma de sujeito de direito, eles se inscrevem em determinadas formações discursivas, que, por sua vez, estabelecem relações com as formações ideológicas que determinam a sua constituição, uma vez que o sujeito discursivo implica a relação do simbólico com o político. Desse modo, o Estado com suas instituições e relações materializadas pela formação social que lhe corresponde, individualiza a forma-sujeito a "reeducando".

\section{O discurso religioso e o processo de individuação do sujeito pelo Estado}

O amparo legal para o desenvolvimento de atividades religiosas em presídios é a Lei 7210, de 11 de julho de 1984, da Lei de Execução Penal, na Seção VI, Artigo 24, que define como o Estado deverá assistir ao sujeito segregado no tocante a assistência religiosa:

Art. 24. A assistência religiosa, com liberdade de culto, será prestada aos presos e aos internados, permitindo-se-lhes a participação nos serviços organizados no estabelecimento penal, bem como a posse de livros de instrução religiosa.

$\S 1^{\circ}$. No estabelecimento haverá local apropriado para os cultos religiosos.

$\S 2^{\circ}$. Nenhum preso ou internado poderá ser obrigado a participar de atividade religiosa. 
Partindo do pressuposto de que a Igreja é constituída por um grupo religioso, organizado e institucionalizado, o poder exercido se justifica pelo imaginário de que os preceitos dogmáticos dominam o mundo sagrado e suas relações com o mundo profano. E Igreja é um dos AIE responsável por manter a ideologia dominante, uma vez que, é propagada a necessidade de submissão à ordem vigente com obediência às regras de "bom comportamento", para a reprodução dos meios de produção que compõem o sistema capitalista. Na visão de Pêcheux (1995):

o sistema das ideologias teóricas, próprio a uma época histórica dada, com as formações discursivas que lhes são correspondentes, é, em última instância, determinado pelo todo complexo com dominante das formações ideológicas em presença (isto é, o conjunto dos aparelhos ideológicos de Estado). (PÊCHEUX, 1995, p. 191)

Pensando o sistema prisional, que também é um aparelho do Estado, mas na posição de ARE, que faz uso de argumentos repressivos e coercitivos para atingir o fim almejado, podemos teorizar que as formações ideológicas que o permeiam na atualidade buscam manter a ideologia dominante através da "reunião" num único espaço (unidade prisional) de igrejas e escolas (ambas AIEs), destacando que esse espaço é também um ARE. Logo, as condições de interpelação do indivíduo que é privado de sua liberdade são ímpares nesse espaço prisional. O limite entre AIE e ARE seria, teoricamente, a aplicação da repressão física e a ideológica, contudo, os discursos dos sujeitos entrevistados apontaram para a coexistência da coerção ideológica e física nas igrejas que funcionam no CRC.

Percebemos, diante das previsões legais destacadas, que é útil para o Estado promover ou reforçar o discurso religioso. Relembramos que Althusser (1985) destacou a igreja, a família, a escola, a mídia, entre outras, como instituições da era moderna que foram transformadas em agentes reprodutores da ideologia dominante.

Cabe destacar que o discurso religioso é um discurso autoritário (ORLANDI, 1996, p. 15), pois o referente está ausente, oculto pelo dizer; não há interlocutores, mas um agente exclusivo, o que resulta na polissemia contida. Orlandi (2013) descreve o discurso religioso como aquele em que fala a voz de Deus: a voz do padre - ou do pastor, ou, em geral, de qualquer representante seu - é a voz de Deus. Dessa forma, no discurso religioso, as lideranças instituídas são consideradas pela comunidade devota como sendo "porta-vozes" do Sagrado; logo, seus discursos não são questionados e sempre obedecidos.

O espaço do CRC, denominado de Unidade I, é dividido entre as seguintes igrejas: Universal do Reino de Deus; Deus é Amor; Assembleia de Deus, e Caminho para Todos. Conforme mencionamos na apresentação, selecionamos para a análise, cinco recortes da entrevista que realizamos com vinte sujeitos segregados (S.S.) ${ }^{4}$, para observarmos o modo como abordam a ação dessas instituições e de que posição-sujeito eles enunciam. Em outras palavras, o processo de individuação do Estado e das instituições, ao individuar o sujeito, faz com que ele ocupe uma posição-sujeito na

\footnotetext{
${ }^{4}$ Por uma questão de ética na pesquisa não identificamos os sujeitos entrevistados; optamos por tratá-los como S.S., seguidos de uma numeração de 0 a 20.
} 
sociedade, faz com que o sujeito se projete dentro, fazendo parte dela, ou fora, mas podendo ser reinserido nas relações sociais. Vejamos:

\section{RECORTE A}

S.S.09: Aqui dentro do CRC funcionam igrejas. Aqui têm obreiros, pastores que ajudam nós. Aqui é mais fácil seguir a Deus. Mas depende da pessoa também, se ela não quiser servir a Deus, têm outras alas também que não são evangélicas. Pra mim eu acho melhor as evangélicas porque ali ele vai conhecendo a verdade, lendo mais a Bíblia, fazendo coisa melhor, positiva. Porque noutra ala que não é evangélica, ali só pensa maldade, briga, discussão, xingamento, palavrão. Eu acho melhor a evangélica porque pra mim faz muita diferença, a gente até comenta com a família, a mudança de jeito, e no convívio a gente vai aprendendo aquelas palavras, palavrão que não convém a gente, chega lá na rua falando isso. A evangélica já muda nosso jeito de falar, de conversar, de agir, de andar na rua, de conviver com a nossa família. (Grifos nossos).

Em seu discurso, S.S.09 descreve o funcionamento das igrejas no CRC e o modo como seus representantes "obreiros" e "pastores" os auxiliam no conhecimento religioso e no cumprimento de sua pena, observando: "aqui é mais fácil seguir a Deus". Também relata como a religião atua na maneira de agir dentro e fora da unidade, marcando essa espacialidade como "aqui" e "lá", respectivamente.

Ao afirmar: "eu acho melhor as evangélicas porque ali ele vai conhecendo a verdade, lendo mais a Bíblia, fazendo coisa melhor, positiva. Porque noutra ala que não é evangélica, ali só pensa maldade, briga, discussão, xingamento, palavrão", S.S.09 enuncia de uma posição-sujeito religiosa, ou seja, esse sujeito individuado pela instituição CRC e os discursos que nela circulam; identifica-se por meio da sua inscrição na formação discursiva religiosa, relativa à formação ideológica, com os discursos que tomam a religião como prática transformadora de sua condição. A esse respeito, ele expõe: "a evangélica já muda nosso jeito de falar, de conversar, de agir, de andar na rua, de conviver com a nossa família", pautado numa projeção imaginária do que a sociedade espera dele, ou seja, seu discurso se sustenta no argumento de que a igreja vai transformálo num indivíduo do bem e, por isso, terá maior aceitação, o que lhe permitirá ser reintegrado ao meio social.

Além disso, o convívio na ala religiosa pode resultar em benefícios ao sujeito, como Silva (2014) afirma em seu trabalho:

o apego a Deus, através da "adesão" a uma religião, principalmente as protestantes, é uma estratégia muito utilizada pelos presidiários como suporte para ampliar as chances de antecipação da liberdade, cumprir a pena com mais conforto e, principalmente, manter um vínculo com pessoas influentes para poder mandar recados, pedir material de higiene pessoal e limpeza, alimentos e também para facilitar os trâmites processuais. (SILVA, 2014, p. 177)

Como já observamos, o discurso é o lugar do trabalho da língua e da ideologia. A religião, através dos representantes da igreja, é forte aliada na promoção da "conversão" dos presidiários que buscam alternativas para facilitar a rotina na prisão e a antecipação da almejada liberdade. No Recorte A, esse gesto produz como efeito a transformação do 
sujeito, pois ele, que tinha um passado marcado por atos maldosos, em função da experiência na prisão, pôde usufruir da oportunidade de se arrepender.

No uso de expressões como o "nós", “a gente”, "nosso jeito", "nossa família”, está configurado o modo de identificação desse sujeito, que individuado pelas instituições se inclui no processo de reintegração social.

A seguir, selecionamos um recorte do discurso do principal líder religioso do $\mathrm{CRC}$, que se denominou um pastor, mesmo tendo sido visto como um "malfeitor" no passado.

RECORTE B.

S.S.12: Quando eu entrei aqui eu ainda era visto como um malfeitor hoje eu sou
líder espiritual aqui de mais de duzentos homens. Eu sou pastor, eu ensino o
que eu aprendi e o que eu quis aprender também, se você não querer não tem
jeito, a pessoa só é ajudada se ela querer ajuda. (Grifos nossos)

Ao dizer: "hoje eu sou líder espiritual aqui de mais de duzentos homens. Eu sou pastor, eu ensino o que eu aprendi”, S.S.12 ocupa a posição-sujeito pastor, inscreve seu dizer numa formação discursiva religiosa e passa a ter determinada autoridade para garantir que suas palavras tenham aceitação de muitos fiéis. São as relações de força, sustentadas no poder desses diferentes lugares e que dizem respeito às formações imaginárias que constituem as diferentes posições. É assim que as condições de produção estão presentes nos processos de identificação dos sujeitos.

A formação ideológica religiosa atua como uma característica dominante realizando a interpelação dele enquanto indivíduo em sujeito. Assim, considerando que a ideologia está presente em todo processo de constituição de dizeres, Pêcheux e Fuchs (1990) assinalam que cada formação ideológica constitui um conjunto complexo de atitudes e de representações. Sendo assim, a formação ideológica atua como um regente que determina o que pode e deve ser dito a partir de uma dada posição. Por isso, podemos afirmar que toda formação discursiva possui uma formação ideológica que a representa. E quando diz: "a pessoa só é ajudada se ela querer ajuda", há um apagamento absoluto de qualquer assunto que possa comprometer o sistema, reverenciado como um local de transformação e aprendizado, no qual só recebe ajuda aquele que manifesta interesse em ser ajudado.

O entrevistado diz que "era visto como um malfeitor, hoje sou líder espiritual", estabelecendo uma relação entre a imagem que o locutor (sujeito preso) faz da imagem que o interlocutor (sociedade) faz dele e a posição que atualmente representa no CRC (pastor). Inscrito na posição-sujeito pastor, ele se identifica com a ideologia religiosa e mobiliza um dizer que remete ao funcionamento do discurso religioso como mecanismo eficaz nas políticas de ressocialização, configurando, por meio do poder disciplinar, a transformação dos sujeitos no interior da unidade prisional, ou seja, ele entra um "malfeitor" e se torna um "líder espiritual", um "pastor".

O que nos chama atenção não é o estatuto da posição que o sujeito passa a ocupar, mas o modo como ele se sente parte integrante do sistema. A nosso ver, o Estado e, 
principalmente, as igrejas atuam nesse processo de identificação dos sujeitos no CRC. Conforme nos ensina Foucault (2013), o poder se deslocou do soberano e passou a existir através da norma; assim, deixou de estar centralizado em uma figura e espalhou-se pela sociedade nas instituições.

Dessa maneira, as igrejas se inserem dentro dos CRC e passam a ter o poder de administrar a rotina dos sujeitos que estão presos, como podemos observar no próximo recorte.

RECORTE C.

S.S. 11: Quando eu cheguei o CRC era de uma forma, hoje já modificou muito desses
quatro anos pra cá. Hoje já está mais bem organizado, temos as igrejas que hoje são
mais de cinquenta por cento de organização. A questão social do reeducando, de
comportamento, hoje está nas mãos das igrejas que são administradas pelos
próprios presos. (Grifos nossos)

Nota-se que S.S.11 se identifica com o discurso da ressocialização que circula no CRC, considerando-a positiva, especialmente, no aspecto da organização e administração feita pelas igrejas nos últimos quatro anos. Ele afirma que: "a questão social do reeducando, de comportamento, hoje está nas mãos das igrejas que são administradas pelos próprios presos". Todavia, como observamos no recorte anterior, as relações de controle e de poder são administradas pelas igrejas, que, por sua vez, são autorizadas a exercer sua doutrina pelo Estado.

Vale ressaltar também que há certa regularidade nos discursos da maioria dos sujeitos entrevistados quanto ao uso da denominação "reeducandos" e/ou "recuperandos", ao invés de "presos", "reclusos". Ou seja, eles repetem os dizeres que perpassam as políticas de reeducação e recuperação dos presos, sentem-se inseridos nesse processo que visa sua reintegração à sociedade.

Ainda sobre essa forma de poder e de controle disciplinar dos sujeitos pelas igrejas, selecionamos mais um recorte para mostrar que nem sempre isso ocorre por meio de uma relação pacífica.

\section{RECORTE D.}

S.S.6: Então eu fiquei na igreja, não consegui subir, só consegui um trabalho aqui mesmo. Fui conseguir subir em 2013 aí depois eu desci. Tô aqui embaixo hoje, tô numa ala evangélica, não porque eu queira, mas não tem como eu entrar para dentro do convívio. (Grifos nossos)

Vemos que a submissão ao poder disciplinar nem sempre é espontânea; muitas vezes, é ocasionada por interesses diversos, como no caso do sujeito S.S.6, que revela estar na ala evangélica porque não consegue entrar para o convívio, o que significa que ele apresenta alguma impossibilidade de relacionamento naquele setor. A palavra "convívio" é recorrente no discurso dos sujeitos que estão presos e se refere a um espaço da prisão onde permanecem as pessoas que não querem ser evangélicas. Nele, é 
permitido o uso de bermudas, bonés, consumo de cigarros, entre outras características da vida de muitos sujeitos fora daquele espaço. A liberdade de atitudes existente nesse espaço encontra limites quando ocorrem desentendimentos em virtude de brigas corporais ou dívidas constituídas entre eles, como no caso de S.S.6, que não é mais aceito dentro do convívio e também não se sente inserido nas alas religiosas, por isso, denuncia os castigos que são praticados.

RECORTE E.

S.S.6: Os castigos acontecem principalmente na Assembleia de Deus aqui, com esse $\mathrm{S}$. Eu já morei com o $\mathrm{S}$. aqui também e uma vez ele botou seis pessoas dirigentes num cubículo e ficaram malhando eles e aí tem os obreiros. E aí ele me acusou que eu estava escondendo que um irmão estava cheirando cocaína e aí eu não caguetei o irmão, sendo que não era verdade. Aí ele pegou e mandou me bater, aí me bateram e eu mandei vários bereus para a direção. A direção não fez nada e aí eu chamei um agente e falei o que estava acontecendo. O agente foi lá e chamou esse S. e aí ele falou: - Você está me denunciando rapaz? Eu falei: - Claro, você mandou me bater, né. Aí ele mandou me bater novamente no dia seguinte. Os próprios membros da ala que faziam isso, os dirigentes de ala e os obreiros. [...] Esse pastor manda bater, junta de dois ou três e batem mesmo. Ele me jurou de morte, disse que vai me matar aqui dentro. (Grifos nossos)

Cabe observar que a produção de sentidos é acompanhada de movimentações nas redes de sentidos que constituem o interdiscurso, de forma tal que os sentidos produzidos pelos discursos, observados no recorte acima, revelam a atuação de um poder coercitivo exercido pelos líderes religiosos. Diante dos discursos: "os castigos acontecem principalmente na Assembleia de Deus aqui" e "aí ele pegou e mandou me bater, aí me bateram", percebemos que o poder exercido perversamente é um poder que se concretiza através das agressões corpóreas, fazendo funcionar uma memória discursiva de atualização das épocas da aplicação das penas cruéis, quando a prisão era para a execução de penas que atingisse o corpo do condenado.

Nesse recorte, destaca-se a coerção física e psicológica como uma prática recorrente no $\mathrm{CRC}$, exercida pelos líderes religiosos que se tornam uma autoridade. Conforme observamos no discurso de S.S.6, o pastor é aquele que dá ordens, ameaça matar e manda outros membros e dirigentes de alas, assim como seus fiéis seguidores, denominados obreiros, baterem em quem descumprir as regras.

Ainda a respeito da prática disciplinar exercida pelas instituições religiosas, selecionamos o último recorte.

\section{RECORTE F.}

S.S.11: Mas hoje as igrejas dentro do sistema elas criaram normas, elas criaram doutrinas, elas criaram formas de punição para aqueles que não seguem às normas, muitas igrejas, em especial a Universal, o que mais me chamou a atenção foi a questão de extorsão. Rola muito dinheiro na igreja, é a questão do dízimo obrigatório, da oferta obrigatória, oferta para comprar piso obrigatória, oferta para arrumar freezer, geladeira, televisão, som. Se você não obedece a eles ou você é mandado para o convívio, transferido para a PCE ou você sofre consequências 


\begin{abstract}
maiores porque eu já vi preso ser amarrado. A direção sabe disso, a unidade sabe disso, que preso já saiu de lá direto para o médico, preso espancado, em especial em algumas igrejas que se denominam pentecostal elas tratam seus membros com mão de ferro. A direção dá muita força para esses pastores agirem assim. Eles não têm formação nenhuma, tem pastores que mal conseguem escrever, mas por ter uma boa oratória, ter conhecimento com a direção aí são nomeados pastores e escolhem seus obreiros que é como se fossem seus guarda costa. (Grifos nossos)
\end{abstract}

Além das leis estatais que regem o espaço prisional, inserem-se as normas disciplinares criadas pelas instituições religiosas que atuam dentro do sistema enquanto um poder regulador, que mais do que os códigos expressos, determina como deve ser o dia-a-dia na prisão. E as alas evangélicas destacaram-se nos discursos dos entrevistados como mantenedoras desse poder disciplinar, como afirma S.S.11, ao referir-se às igrejas: “elas criaram formas de punição para aqueles que não seguem às normas".

Sendo a maioria dos entrevistados obedientes às "doutrinas" criadas pela igreja no interior do CRC, destacamos que a disciplina de seus corpos tem alcançado o objetivo da docilidade citada por Foucault (2013), não fossem os poucos que disso escapam e, além disso, o bom comportamento se dá também pelo medo que eles têm de serem transferidos do CRC para outras unidades prisionais, em especial a PCE, uma vez que essa prática se constitui como uma punição exemplar àqueles que não seguem às regras estabelecidas, conforme declara o S.S.11: "se você não obedece a eles ou você é mandado para o convívio, transferido para a PCE ou você sofre consequências maiores porque eu já vi preso ser amarrado".

Vemos que a igreja atua onde o Estado falha. Por um lado, a doutrina religiosa age nos espaços que escapam às leis, mas não competem com elas. Por outro, os mecanismos disciplinares que garantem a eficácia e a manutenção dessas normas são cruéis e questionáveis. Essas práticas não são condizentes aos princípios humanitários. Todavia, não são os agentes prisionais que aplicam os tais castigos corporais. A nosso ver, a humanidade que se resguarda é a dos que exercem o poder estatal e não a de quem comete crimes.

Segundo o sujeito entrevistado, apesar de a Direção ser informada sobre o que ocorre, ela não interfere na ordem estabelecida pelos presos que se tornam representantes das igrejas. Dessa forma, o Estado se desresponsabiliza pela prática desumana, uma vez que a assistência religiosa aos sujeitos presos está assegurada juridicamente.

De acordo com S.S.11, a direção das unidades prisionais tem interesse na obediência dos presos, pois, afirma ele: "a direção sabe disso, a unidade sabe disso" e "a direção dá muita força para esses pastores agirem assim”. Parece-nos que, para o funcionamento do sistema carcerário, o importante é manter a submissão dos sujeitos segregados, pois quanto mais obediente o indivíduo for, mais útil ele será.

E quanto à formação dos pastores, o S.S.11 diz: "eles não têm formação nenhuma, tem pastores que mal conseguem escrever, mas por ter uma boa oratória, ter conhecimento com a direção aí são nomeados pastores". São as relações de força estabelecidas entre o 
poder estatal e as igrejas que legitimam o sujeito preso a ocupar a posição de "pastor", processo que o investe de autoridade frente às falhas do Estado.

Desse modo, a religião passa a exercer também um poder político na gestão carcerária, pois a prática religiosa se configura como um dos mecanismos para promoção da transformação dos sujeitos segregados, estando inserida nas políticas públicas como colaboradora do processo de ressocialização. Sua atuação nos presídios é legitimada tanto pelo sistema jurídico quanto pelo administrativo.

De acordo com Silva (2014), a religião na prisão se apresenta como o elemento provocador da metamorfose do sujeito presidiário que, quando adere a uma religião, acredita que está afetado pelo plano divino, é capaz de pedir perdão, de se arrepender e de admitir seus erros, aqueles que o levaram à prisão, com a consequente possibilidade de ser perdoado pela sociedade e a ela reintegrado, deixando de ser o "cara do mal" e passando a ser "o cara do bem".

Convém lembrar que, no passado, os sujeitos segregados mostravam seu poder contra o sistema através das grandes rebeliões. O Estado, por sua vez, mostrava, apesar de temporária, toda sua força no abafamento desses levantes, recorrendo à força da policial militar. Hoje, temos o uso de outras estratégias por parte de ambos: os sujeitos presos acreditam dominar as unidades de uma maneira "camuflada" pela religião e o Estado garante o apoio à expansão das igrejas para conseguir a "pacificação" dos presídios.

Desse modo, o processo de ressocialização almejado pelo Estado vai se delineando de modo singular com a inserção de outras instituições. Pois, segundo Costa (2008, p. 126), "o presídio é lugar de individualização do sujeito preso e ao mesmo tempo é espaço de interpretação, passagem e permanência".

A evangelização nas prisões, vista com bons olhos pela sociedade e pelo Estado, ajuda controlar os sujeitos segregados para que não venham a se manifestar contra o poder público diante das falhas deste. A nosso ver, organizações criminosas e igrejas evangélicas agem nos presídios numa espécie de vazio deixado pelo Estado.

\section{Algumas considerações}

Considerando que a assistência religiosa no sistema carcerário brasileiro, prevista nas legislações para garantir ao preso a possibilidade de (re)estabelecer laços sociais que deem sentido à sua pertença social, na prática, estabelece uma divisão entre sujeitos e sentidos, pois para quem cumpre pena no CRC, existem espaços evangélicos e os espaços não evangélicos (chamados de ímpios).

A nosso ver, no vácuo que o Estado deixa, outras organizações, como as igrejas, se fortalecem e ocupam o espaço prisional com a justificativa de garantir o direito à assistência religiosa e colaborar com o processo de ressocialização dos sujeitos segregados. Contudo, constrói-se um sistema hierárquico, estabelecendo a cobranças de dízimo e outras práticas questionáveis. Há uma atribuição de poder aos líderes das igrejas 
enquanto representantes de Deus (e do Estado), sendo, de certa forma, autorizados a administrarem o CRC, mesmo agindo por meio da intimidação. Essa prática se justifica pelo imaginário social e funciona eficazmente na prisão.

Nessa direção, podemos afirmar que a prática religiosa atua no modo como os sujeitos vão se significar para si e para os outros, articulada ao modo como a sociedade os significa, pois, os discursos sobre a reintegração social produzem no sujeito a ilusão de ele fazer parte do processo de ressocialização. Pensando as condições de produção de sentidos (e de existência) desses sujeitos segregados no CRC e nas relações de força e de poder simbolizadas que funcionam no imaginário em que estão mergulhados, significados, sua conversão gera simpatias por parte do Estado, já que se entende que os evangélicos causam menos conflitos.

Em outras palavras, o sujeito, ao produzir seu discurso, o faz afetado pela ideologia e pelo inconsciente e, por conseguinte, seu dizer inscreve-se, sem que ele perceba, sempre, por identificação, em uma formação discursiva que autoriza certos discursos e impede outros (PÊCHEUX, 1990).

\section{Referências bibliográficas}

ADORNO DE OLIVEIRA, L.L. A delinquência e a (im)possibilidade de se significar como autor no discurso matemático. Tese. Doutorado em Linguística. Programa de PósGraduação em Educação para a Ciência e a Matemática. Universidade Estadual de Maringá, 2015.

ALTHUSSER, L. Aparelhos Ideológicos de Estado. Rio de Janeiro: Graal, 1985.

BRASIL. Lei de Execução Penal no 7210 de 11 de julho de 1984. Disponível em <http://www.planalto.gov.br/ccivil_03/leis/17210.htm>; acesso em out. 2015.

CAPELLER, W. O Direito pelo avesso: análise do conceito de ressocialização. Temas IMESC [Sociedade, Direito, Saúde]. São Paulo, vol. 2, n. 2, p.127-134, dez. 1985.

COSTA, G.C. da. Linguagens em funcionamento: sujeito e criminalidade. Dissertação. Mestrado em Linguística. Instituto de Estudos da Linguagem, Universidade Estadual de Campinas, 2008.

FOUCAULT, M. [1987]. Vigiar e punir: nascimento da prisão. Trad. Bras. 41 ${ }^{\mathrm{a}}$. ed. Petrópolis, RJ: Vozes, 2013.

HAROCHE, C. Fazer dizer, querer dizer. São Paulo: Hucitec, 1992.

MAIA, C.N. et al. (Orgs.). História das prisões no Brasil. vol. I. Rio de Janeiro: Rocco, 2009. 
ORLANDI, E.P. Formação ou capacitação: duas formas de ligar sociedade e conhecimento. Em: FERREIRA, E.L.; ORLANDI, E.P. (Orgs.). Discursos sobre a inclusão. Niterói: Intertexto, 2014. p.142-186.

Análise de Discurso: princípios e procedimentos. 10ª . ed. Campinas: Pontes Editores, 2013.

(Org.) Discurso e políticas públicas urbanas: a fabricação do consenso. Campinas, SP: Editora RG, 2010. 1996.

A linguagem e seu funcionamento: as formas do discurso. Campinas: Pontes,

PÊCHEUX, M. Semântica e discurso: uma crítica à afirmação do óbvio. Trad. Bras. $2^{\mathrm{a}}$. ed. Campinas, SP: Editora da Unicamp, 1995.

; FUCHS, C. A propósito da Análise Automática do Discurso: atualizações e perspectivas. Em: GADET, F.; HAK, H. (Orgs.). Por uma análise automática do discurso. Campinas: Editora da Unicamp, 1990.

SILVA, V.L. da. Sujeitos segregados: a língua e a história na produção epistolar de presidiários. Tese. Doutorado em Linguística. Instituto de Estudos da Linguagem, Universidade Estadual de Campinas, 2014.

Artigo recebido em: junho de 2016.

Aprovado e revisado em: julho de 2016.

Publicado em: agosto de 2016

\section{Para citar este texto:}

BARRETO, Mariclei Eduardo Cintra; BRESSANIN, Joelma Aparecida. O funcionamento do discurso religioso nas políticas de ressocialização. Entremeios [Revista de Estudos do Discurso], Seção Temática [Os discursos sobre segurança em meio a políticas e processos de significação], Programa de Pós-graduação em Ciências da Linguagem (PPGCL), Universidade do Vale do Sapucaí, Pouso Alegre (MG), vol. 13, p. 263-279, jul. - dez. 2016.

DOI: http://dx.doi.org/10.20337/ISSN2179-3514revistaENTREMEIOSvol13pagina265a281 